\title{
A new species of Quadrivisio (Amphipoda, Maeridae) from coastal tropical lagoons (Benin, West Africa)
}

\author{
Pierre GNOHOSSOU ${ }^{1}$ \& Christophe PISCART ${ }^{2, *}$ \\ ${ }^{1}$ University of Abomey-Calavi, Laboratoire d'Hydrobiologie et d'Aquaculture, \\ B.P.526 Cotonou, Benin. \\ ${ }^{2}$ Univ Rennes, CNRS, ECOBIO - UMR 6553, F-35000, Rennes, France. \\ ${ }^{*}$ Corresponding author: christophe.piscart@univ-rennes1.fr \\ ${ }^{1}$ Email: gnonhossou@yahoo.com \\ ${ }^{1}$ urn:1sid:zoobank.org:author:15B6EC94-39F0-4621-984D-4083C0D9B3CC \\ ${ }^{2}$ urn:lsid:zoobank.org:author:E652BD99-AA01-44BC-8DAC-EB8B3D290233
}

\begin{abstract}
During a recent investigation of the benthic macrofauna from coastal lagoons of southern Benin (Ahémé, Nokoué and Porto-Novo lagoons), a new species of the amphipod genus Quadrivisio Stebbing, 1907, Q. laleyei sp. nov. was collected by means of different quantitative and non-quantitative methods (plastic baskets, wooden artificial substrates, uprooted plants and Surber net) in their intertidal macrophyte zone. The new species can be easily distinguished from most of the other species of the genus by the setation of the mandibular palp and telson and a reduced number of articles (4-6) on the accessory flagellum of the first antenna. The new species closely resembles to $Q$. lutzi (Shoemaker, 1933) but clearly differ by a reduced armature of the urosomites 1 and 2 and by the geographical distribution (Q. lutzi being known only in Central and South America). Ecological data and an updated key to a species in the genus Quadrivisio are provided.
\end{abstract}

Keywords. Brackish water, Eastern Atlantic, littoral lagoons, Peracarida.

Gnohossou P. \& Piscart C. 2019. Anew species of Quadrivisio (Amphipoda, Maeridae) from coastal tropical lagoons (Benin, West Africa). European Journal of Taxonomy 533: 1-14. https://doi.org/10.5852/ejt.2019.533

\section{Introduction}

Brackish littoral lagoons are highly productive ecosystems, capable of sustaining high levels of biodiversity (Albaret 1994; Baran 1999; Pombo et al. 2002; Villanueva et al. 2006; Blaber 2008).

During a recent research programme (CORUS joint project between Université d'Abomey-Calavi Bénin, Ecole Nationale Agronomique de Toulouse - France and the International Foundation for Science) exploring the ecological functioning of coastal tropical lagoons from southern Benin (Ahémé, Nokoué, and Porto-Novo lagoons), novel investigations were conducted examining benthic communities, with the aim to provide a complete faunal inventory of these environments (Gnohossou 2006). New samples were taken by focusing on the collection of poorly known epi- and infaunal peracarids assemblages. 
The present paper describes a new epibenthic amphipod, attributed to the genus Quadrivisio Stebbing, 1907, which was collected from three Benin lagoons. Ecological comments about this new species are included.

\section{Material and methods}

\section{Study sites}

The three lagoons studied are located in the southern part of Benin, West Africa; close to the Atlantic coast (Fig. 1). The Nokoue lagoon is the largest brackish water body in approximately $150 \mathrm{~km}^{2}$ at low water level (Lalèyè 1995). This semi-open lagoon is directly connected to the Atlantic via the Cotonou channel (4.5 km long), and receives fresh water from the northern Sô and Ouémé rivers (flooding season is between July and November, with low water season between December and June). The maximum water depth is $3.4 \mathrm{~m}$ in front of the Cotonou channel during flooding season (Adounvo et al. 2007). Water temperatures fluctuate between 25.2 and $33.1{ }^{\circ} \mathrm{C}$ at the surface, and between 25.3 and $30.2^{\circ} \mathrm{C}$ at the bottom of the lagoon, with an annual mean of $27.8^{\circ} \mathrm{C}$ (Lalèyè et al. 2003). Salinity ranges from 0 during the flooding season, to 31 g.L $\mathrm{L}^{-1}$ during the low water season (Lalèyè et al. 2003; Adounvo et al. 2007). The whole lagoon exhibits the same spatio-temporal fluctuations (Villanueva 2004). Dissolved oxygen concentrations are highly variable: from a minimum of $0.5 \mathrm{mg} . \mathrm{L}^{-1}$ in highly polluted zones (e.g. Ganvié) to a maximum of $9.0 \mathrm{mg} . \mathrm{L}^{-1}$ in zones close to the sea (e.g. Zogbo) (Lalèyè et al. 2003). The bottom of the lagoon is sandy, muddy or clayed according to the specific sampling site (Gnohossou 2006).

The eastern Porto-Novo lagoon covers a total area of $35 \mathrm{~km}^{2}$, and has an average water depth of $2.2 \mathrm{~m}$; it is linked with the Nokoué lagoon by the Totchè channel ( $5 \mathrm{~km}$ long; 200-300m wide), and to the Lagos lagoon (Nigeria) by a channel $100 \mathrm{~km}$ long. Water temperatures fluctuate between 22.3 and $31.2^{\circ} \mathrm{C}$ (Lalèyè 1995 ), and salinity ranges from 0 to 22 g.L. $\mathrm{L}^{-1}$ (Lalèyè 1995). The dissolved oxygen concentrations fluctuate between 0.7 and $9 \mathrm{mg}^{-L^{-1}}$ (Lalèyè 1995). Lagoon bottoms are generally muddy and clayed.

The western Ahémé lagoon has a total area of $85 \mathrm{~km}^{2}$, and is connected to the Atlantic Ocean by the Aho channel $(16 \mathrm{~km})$. Its mean water depth is approximately $1 \mathrm{~m}$, but a maximum depth of $2 \mathrm{~m}$ was registered during seasonal flooding. It receives freshwater from the Kouffo and Mono rivers. Salinity in the lagoon varies from 0 (flooding period) to $18 \mathrm{~g} . \mathrm{L}^{-1}$ (low water period) (Niyonkuru 2007). The dissolved oxygen concentrations vary from 2.52 to $5.89 \mathrm{mg}$. $\mathrm{L}^{-1}$, and the mean monthly water temperature is $28^{\circ} \mathrm{C}$ (Niyonkuru 2007).

\section{Lagoonal peracarid fauna sampling}

Samplings were performed at low water level and during the flooding season from 2002-2003 in the Nokoué lagoon and additional samplings were realized in September 2007 in the Ahémé and PortoNovo lagoons.

Plastic baskets (area: $314 \mathrm{~cm}^{2}$; height above bottom: $14 \mathrm{~cm}$; mesh size of lateral walls: $0.5 \mathrm{~mm}$ ) half filled with local sediment, were laid on the bottom of the lagoon for one month, before recovery for analysis of the colonizing fauna, which were retained by a $200 \mu \mathrm{m}$ sieve.

Epibenthic hauls were carried out with a modified Surber net sampler (height: $30 \mathrm{~cm}$; width: $50 \mathrm{~cm}$; mesh size: $200 \mu \mathrm{m}$ ), which was towed over the bottom at a variable speed for a distance of about $3 \mathrm{~m}$, estimated area sampled during one haul: $1.5 \mathrm{~m}^{2}$. 
We used an additional semi-quantitative method, constituted by wooden artificial substrates: a bundle of firewood (height: $30 \mathrm{~cm}$, diameter: $10 \mathrm{~cm}$; mean firewood diameter: $3 \mathrm{~cm}$ ) vertically fixed on a stake at $30 \mathrm{~cm}$ below the water surface of the lagoon, recovered one month later for analysis of the colonizing fauna, retained by a $200 \mu \mathrm{m}$ sieve.

Finally, from the macrophyte substrata (Paspalum vaginatum Sw. and Eichornia crassipes (Mart.) Solms: two or three plants were uprooted by hand from each sampling station, and washed on a $200 \mu \mathrm{m}$ sieve, to collect vegetation-associated fauna.

These sampling methods were carried out at five sites close to the Nokoué lagoon (Fig.1). The three northern sites were influenced by river runoffs: mouth near the Ouémé River (MOR), Ganvié and Vêki near the Sô River. The two southern sites, Zogbo and Canal, were influenced by oceanic water inputs through the neighboring Cotonou channel. Ganvié is considered the most polluted area of the lagoon, due to the proximity of an important agglomeration (Gnohossou 2006).

Only the Surber and macrophyte methods were used in the other lagoons, at four of the sampling sites in the Ahémé lagoon, the most polluted sites were the two southern ones, at three sampling sites in the Porto-Novo lagoon, the less polluted of the three ecosystems studied (Gnohossou 2006).

The benthic fauna collected was preserved in a solution of formaldehyde $(10 \%)$ with lagoon water, before subsequent sorting at the laboratory. After separation from the remaining material, the Quadrivisio specimens were examined under a Wild M5 dissecting microscope. For the observations, some specimens were subject to the following successive treatments: (1) washing in ethanol solution with lactic acid, (2) staining with pink lignin solution overnight, and (3) dissecting and mounting in Euparal under a stereomicroscope SZX16 (Olympus@).

The total length of the specimens was measured with a microscope eyepiece, from the front of the head to the tip of the telson.

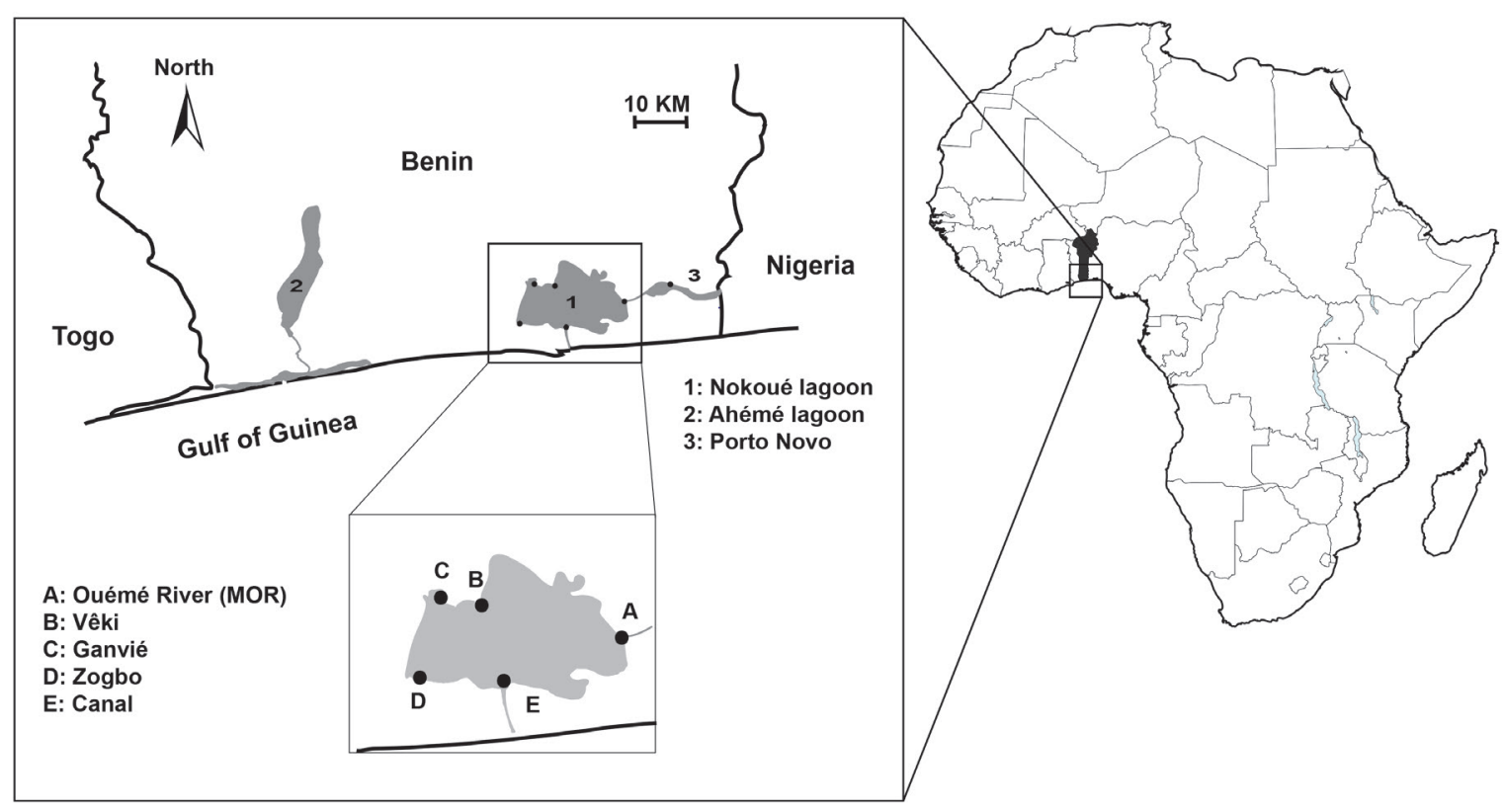

Fig. 1. Location of sampling sites in Benin. 


\title{
Institutional abbreviation
}

MNHN = Muséum national d'Histoire naturelle, Paris, France

\section{Results}

\author{
Order Amphipoda Latreille, 1816 \\ Suborder Senticaudata Lowry \& Myers, 2013 \\ Family Maeridae, Krapp-Schickel, 2008 \\ Genus Quadrivisio Stebbing, 1907 \\ Quadrivisio laleyei sp. nov. \\ urn:lsid:zoobank.org:act:AE890355-182D-4473-ABF2-A90DFE1E1208
}

Figs 2-5, Tables 1-2

\section{Diagnosis}

The new species belongs to the genus Quadrivisio, recognized by the shape of their eyes for which ommatidia are almost split into two pairs on each side of head, antenna 1 with a very long flagellum, propodus of male gnathopod 2 very large, uropod 3 with rami foliaceous. Accessory flagellum of antenna 1 with 4-6 articles. Article 3 of mandibular palp slightly shorter than article 2 and armed with two setae. Propodus of male gnathopod 1 almost rectangular. Gnathopod 2 sexually dimorphic. Epimeral plates $2-3$ with a small tooth at posterodistal angle, but lacking supernumerary teeth on posterior margin. Pleonite and urosomites smooth. Urosomite 2 with posterodorsal robust setae (one on each side). Telson without spines or setae along inner margin of each lobe.

\section{Etymology}

The epithet laleyei refers to the name of the Professor Philippe A. Lalèyè who initiated the studies of macrofauna from lagoons in Benin. The name is a noun in the genitive case.

\section{Material examined}

\section{Holotype}

BENIN • $\widehat{J}$ (7.5 mm); Porto Novo city, Porto-Novo lagoon, 20-30 cm bottom depth, Kessounou station, muddy sediment; $06^{\circ} 28^{\prime} 05.5^{\prime \prime} \mathrm{N}, 02^{\circ} 36^{\prime} 56.2^{\prime \prime} \mathrm{E}$; water temperature: $28^{\circ} \mathrm{C}$; water salinity: 4 g.L $\mathrm{L}^{-1}$; Jun. 2007; collected with live macrophytes (Paspalum vaginatum Sw.), uprooted by hand; MNHN IU-2017209.

\section{Paratypes}

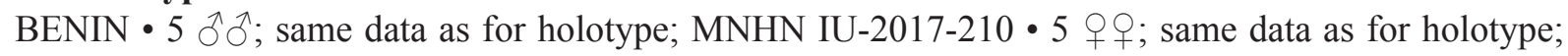
MNHN IU-2017-211.

\section{Other material examined}

BENIN • Around 50 specimens; Porto Novo city, Porto-Novo lagoon, 20-30 cm bottom depth, Kessounou station, muddy sediment; $06^{\circ} 28^{\prime} 05.5^{\prime \prime} \mathrm{N}, 02^{\circ} 36^{\prime} 56.2^{\prime \prime} \mathrm{E}$; water temperature: $28^{\circ} \mathrm{C}$; water salinity: 4 g.L.-1; Jun. 2007; collected with live macrophytes (Paspalum vaginatum Sw.), uprooted by hand.

\section{Description}

\section{Male}

CepHaLon. Lateral cephalic lobes broad, rounded, with anteroventral notch, anteroventral corner rounded. Eyes constricted in center, never divided into two parts (Fig. 2A). Antenna 1 longer and more slender than antenna 2, sparsely setose (Fig. 2C); peduncle much shorter than main flagellum, article 1 a shorter 


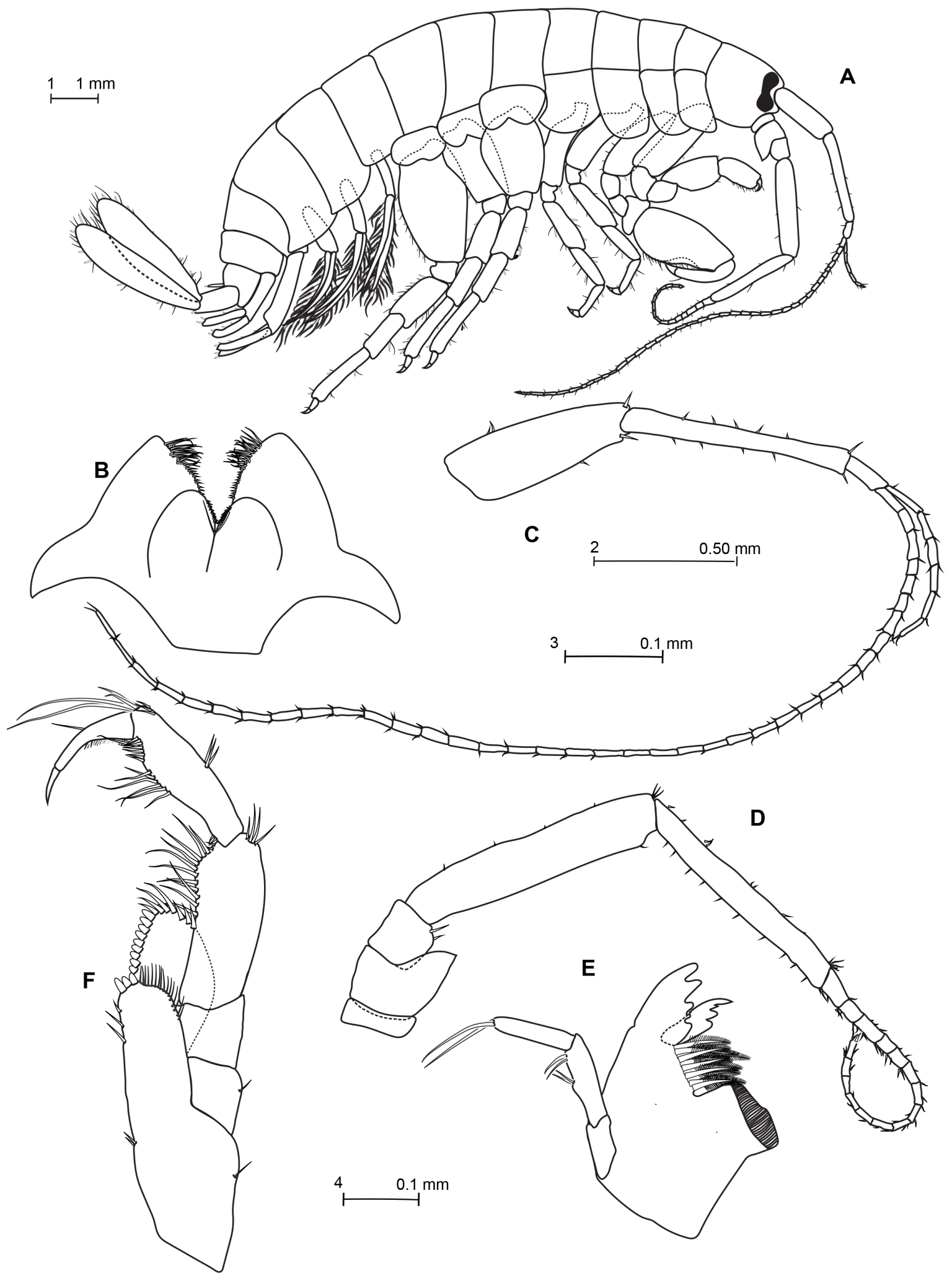

Fig. 2. Quadrivisio laleyei sp. nov., Ô, holotype, 7.5 mm, MNHN IU-2017-209. A. Habitus (scale 1). B. Lower lip (scale 3). C. First antenna (scale 2). D. Second antenna (scale 2). E. Left mandible (scale 4). F. Maxilliped palp (scale 3). 
than article 2 , article 3 very short $(0.2 \times$ length of the article 2$)$; main flagellum with up to 38 articles unequal in length and in width; accessory flagellum well developed composed of six articles. Antenna 2 peduncle longer than the flagellum, article 4 and 5 similar in length (Fig. 2D); glandular cone on the peduncular article 2 prominent, reaching to end of peduncular article 3; flagellum with up to 15 articles. Lower lip with weakly-developed inner lobes, more pubescent outer lobes; mandibular lobes rather short and rounding (Fig. 2B). Mandibles asymmetrical. Left mandible incisor process dentate, with four chitinized teeth (Fig. 2E). Lacinia mobilis dentate, with four chitinized teeth, setal row with 6 plumose

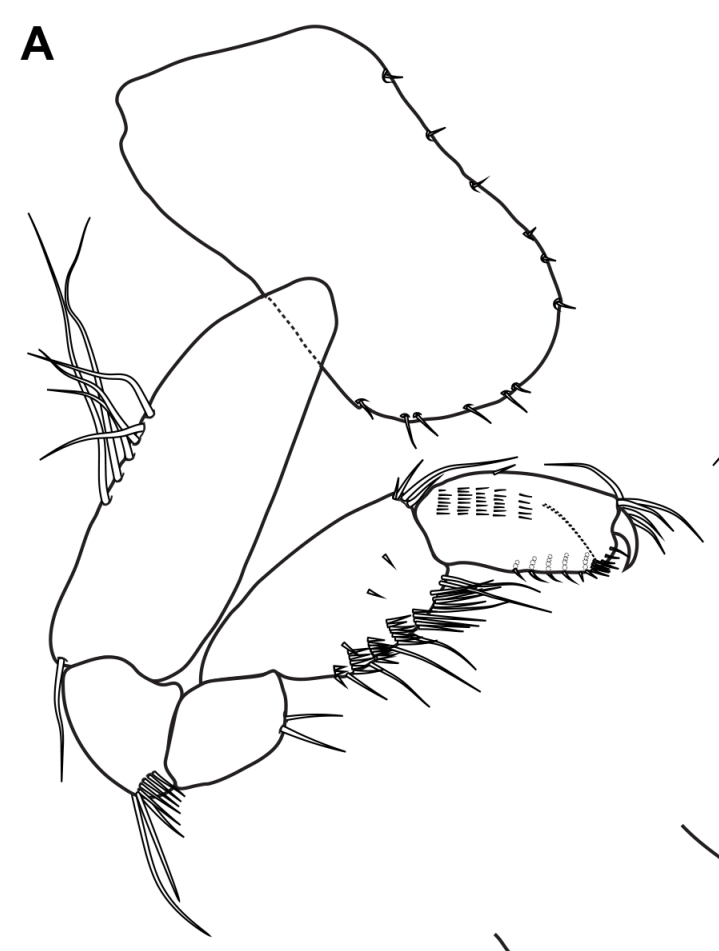

A

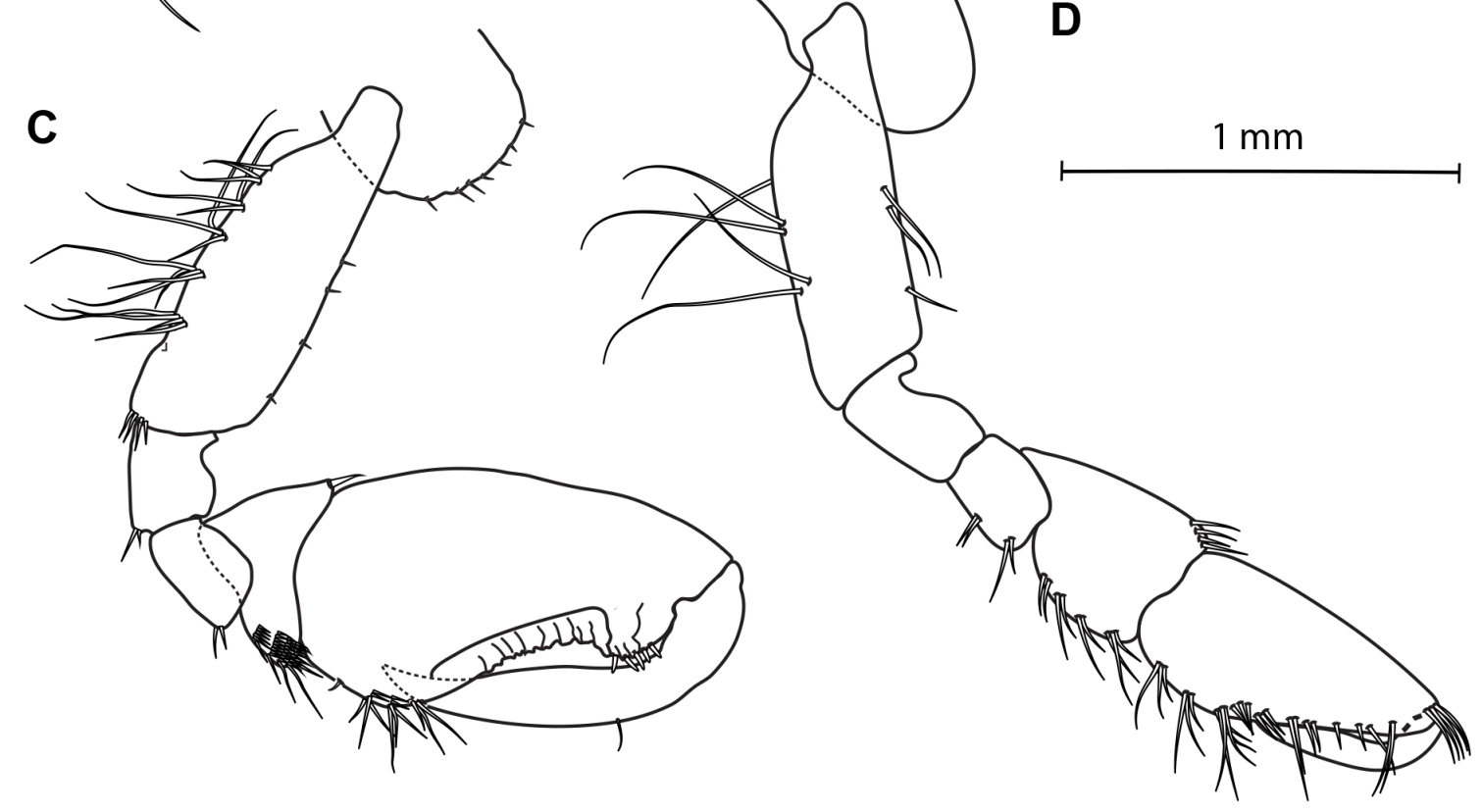

Fig. 3. Quadrivisio laleyei sp. nov. A., C. Holotype, đ, 7.5 mm, MNHN IU-2017-209, gnathopod. B., D. Paratype,, , $7.0 \mathrm{~mm}$, MNHN IU-2017-211, gnathopod. 
setae, molar process well developed and columnar, triturative. Palp article 1 shorter than article 2, article 2 slightly longer than article 3 with two setae on outer margin and two distal setae, article 3 rectolinear with two long terminal setae slightly longer than the article. Maxilla 1 and 2 do not present specific characteristics (not drawn). Maxilla 1 inner plate setose along entire inner margin and bearing a submarginal row of setae, outer plate bearing seven stout curved serrate setae, palp with distal article longer than proximal one, distal article with five terminal short stout setae and three subdistal slender setae on distal article. Maxilla 2 inner margin of inner plate of with double row of setae, unequal in

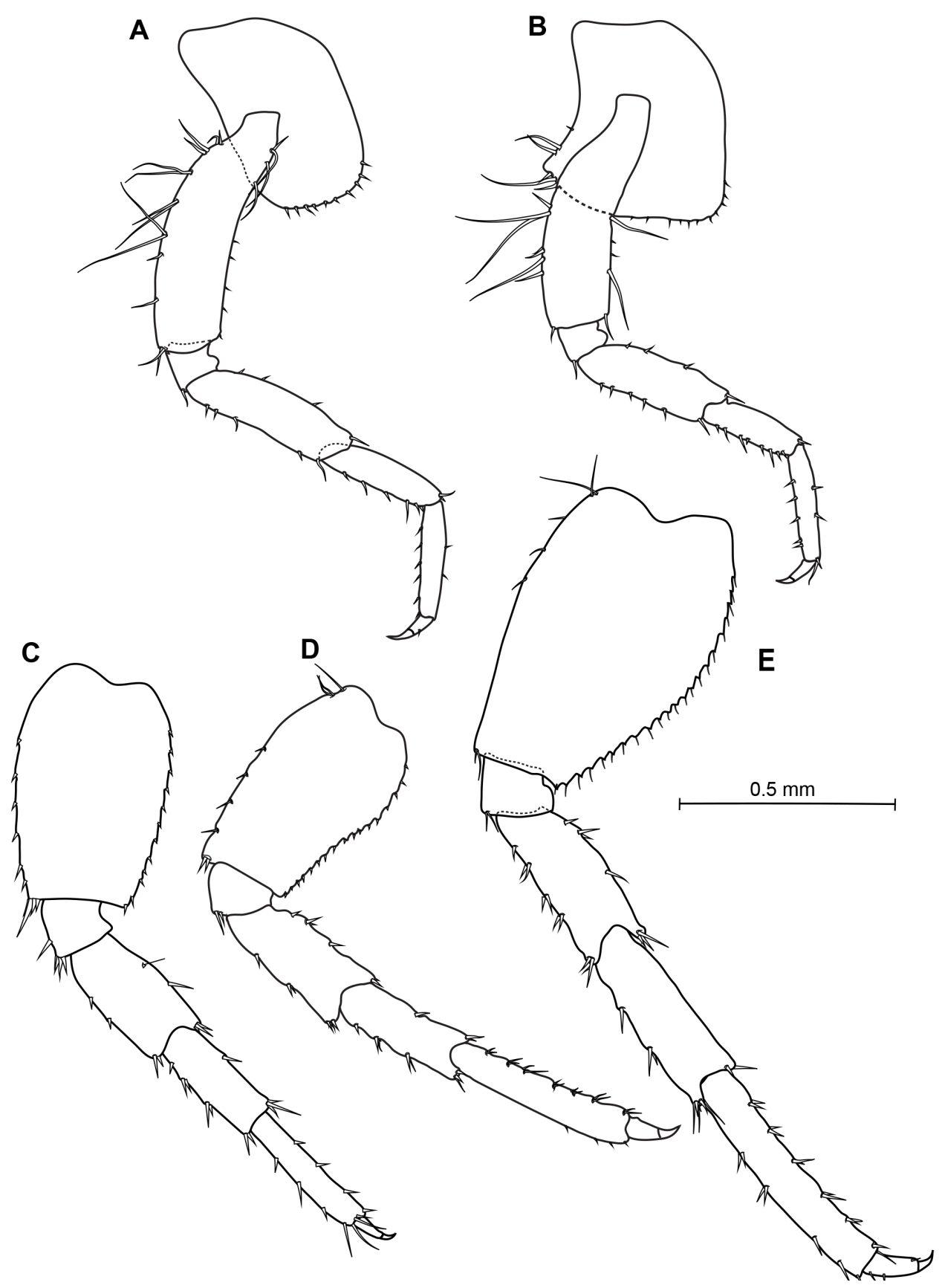

Fig. 4. Quadrivisio laleyi sp. nov. A-B., D-E. Holotype, ô, 7.5 mm, MNHN IU-2017-209. C. Paratype, §, 7.6 mm, MNHN IU-2017-210. A. Pereopod 3. B. Pereopod 4. C. Pereopod 5. D. Pereopod 6. E. Pereopod 7. 
length, and third oblique one on posterior face; outer plate with double rows of terminal and subterminal setae; inner and outer plates of maxilliped rather short (Fig. 2F); inner plate reaching to about middle of outer plate and bearing three terminal robust setae; outer plate reaching to about middle length of palp article 2, the ensemble of the distal margin and the distal part of the outer margin bear seven slender setae; palp article 3 slightly shorter than article 2, article 4 shorter than article 3 with a row of fine short setules on inner margin.

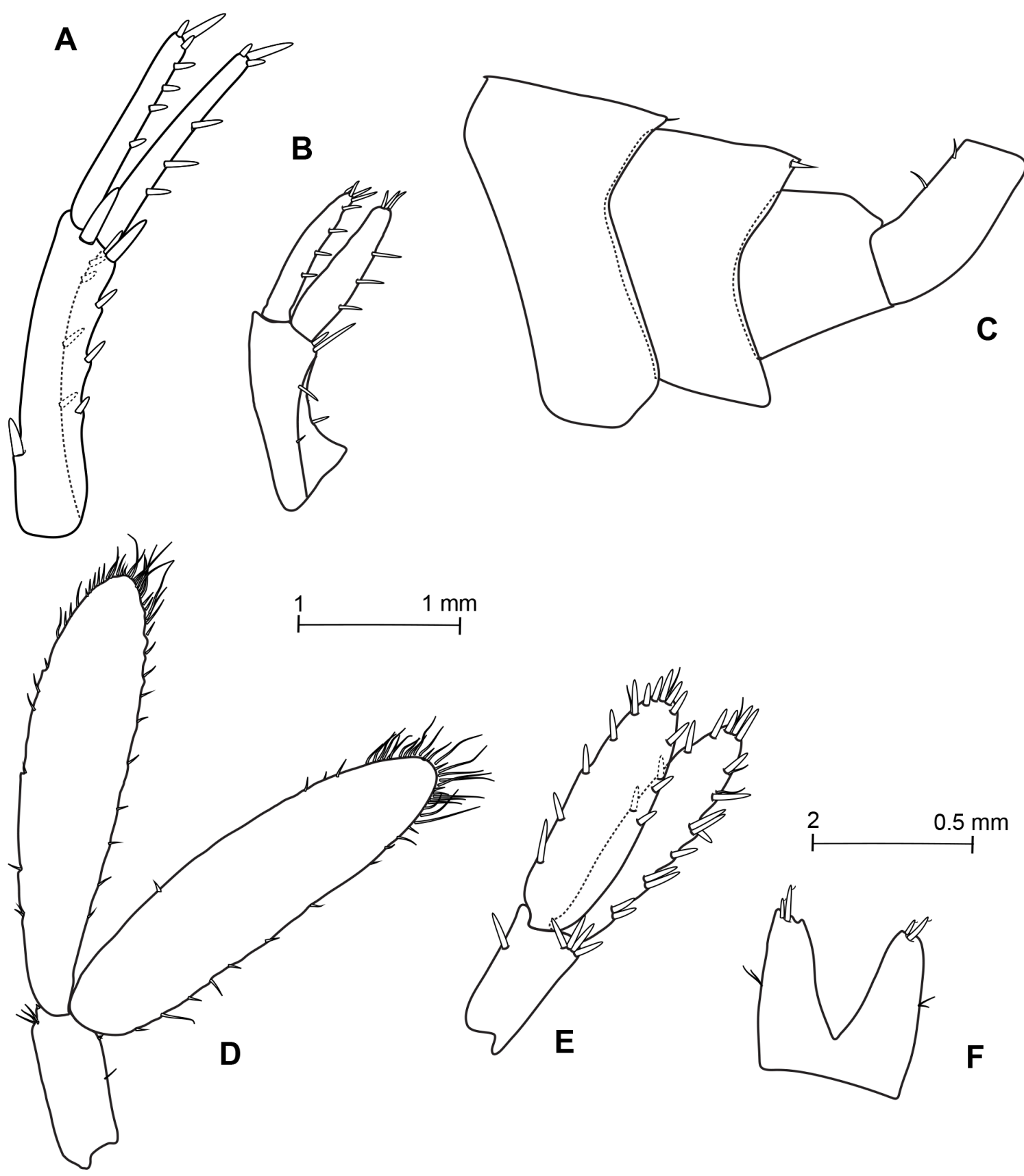

Fig. 5. Quadrivisio laleyi sp. nov. A-D., F. Holotype, ô, 7.5 mm, MNHN IU-2017-209. E. Paratype, o , 7.0 mm, MNHN IU-2017-211. A. Male uropod 1 (scale 1). B. Male uropod 2 (scale 1). C. Male urosome (scale 1). D. Male uropod 3 (scale 1). E. Female uropod 3 (scale 1). F. Male telson (scale 2). 
Thorax. Coxae 1-4 equal in depth and deeper than coxa 5. Coxa 1 anteroventral corner not produced forward, lower margin evenly rounded with few small setae and bearing a weak notch horned with one seta at hind corner. Coxae 2-3 lower margin evenly rounded with few small setae, with notch at hind corner; a seta is inserted in that notch. Coxa 4 posteriorly excavate so as to fit the front margin of coxa 5. Coxae 5-7 bilobed. Coxa 7 smallest. Coxal gills simples on each pereopod. Gnathopod 1 more slender than gnathopod 2, subchelate (Fig. 3A); basis subequal in length to the depth of coxa 1; carpus subequal to propodus, with hind margin furnished with transverse rows of setae; propodus subrectangular, slightly narrowing distally, palm nearly transverse, very convex and undefined; dactylus curved to fit palm, very stout at base but attenuated toward apex. Gnathopod 2 robust, subchelate; basis shorter than propodus (Fig. 3C); merus with quadrate posterodistal corner bearing two short setae; carpus compressed; propodus strong and stout, widest proximally, proximal hind margin with transverse group of setae, palm very oblique, defined proximally by a tuft of small and long setae and distally by a rounded process adjacent to dactylus hinge, bearing at least four stout short setae; dactylus stout, slightly curved proximally, apically subacute. Pereopods 3-4 subequal in length and morphologically similar (Fig. 4A, B), weakly setose, shorter than subsequent pereopods; basis not expanded. Pereopods 5-7 increasing length from P5 to P7; basis expanded with posterior margin convex and minutely serrate, with short setae, posterodistal corner subquadrate; merus, carpus and propodus armed with spines only (Fig. 4C, D-E).

ABdomen. Epimeron 1 posterior and ventral margins smooth. Epimera 2-3 with a small tooth at posterodistal angle. Urosome posterodorsal margins smooth. Urosomite 1 with 1-2 short dorsolateral setules (Fig. 5C). Urosomite 2 with a dorsolateral robust setae (one on each side). Uropod 1 peduncle with a basofacial seta and a robust apical seta between rami, longer than rami, of which the inner is slightly the longer (Fig. 5A). Uropod 2 the shortest uropod; peduncle slightly longer than inner ramus; inner ramus slightly longer than outer ramus (Fig. 5B). Uropod 3 peduncle much shorter than rami (around $1 / 3$ and $1 / 4$ of rami), reaching to end of inner ramus of uropod 2, rami subequal in length, broad, flat, edged with few short setae, terminally rounding and adorned with longer setae (Fig. 5D). Telson slightly shorter than uropod 3 peduncle, almost cleft to base, lobes widely divergent, apex truncated, with 2-3 short stout flagellated spines, outer margins with two sensorial setules, inner margins without setae (Fig. 5F).

\section{Female}

ABDomen. Gnathopod 2 sexually dimorphic (Fig. 3C, D); propodus comparatively much smaller; palm evenly and slightly convex, without either the protuberance near the hinge or the membranous cushion. Uropod 3 proportionally much shorter than males but much more spinose (Fig. 5D, E). Oostegites narrow and present from gnathopods to pereopod 6.

\section{Differential diagnosis}

The genus Quadrivisio currently contains eight species: Q. aviceps (K.H. Barnard, 1940); Q. bengalensis Stebbing, 1907; Q. bousfieldi Karaman \& Barnard, 1979; Q. chevreuxi Gordon \& Monod, 1968; Q. lobata Asari, 1983; Q. lutzi (Shoemaker, 1933); Q. meufong Hughes \& Kaji, 2016 and Q. sarina Lowry \& Springthorpe, 2005.

Quadrivisio lalaeyei differs from most of the known species by several characteristics (see updated key of the genus after Hughes \& Kaji 2016): the lack of carina on pleonites or urosome; the setation of the mandibular palp (Q. bousfieldi) and telson (Q. bengalensis, Q. lobata and $Q$. sarina); the shape of pereopod 7 (Q. sarina), by the number of article on the accessory flagellum of antenna 1 (Q. aviceps, Q. meufong). Quadrivisio lalaeyei closely resembles to $Q$. lutzi but differs by several characters such as the lack of carina on urosomite 2 in females or juveniles, the presence of the dorsolateral robust setae on urosomite 2 , the shape of the eyes, the article 2 of the mandibular palp slightly longer than the third. 


\section{Identification key to known species of Quadrivisio (updated after Hughes \& Kaji 2016)}

1. Carina absent on pleonites or urosome in males and females

- Carina present on pleonites or urosome in males and/or females .................................................. 6

2. Male gnathopod 2 propodus palm without posterodistal shelf

Q. chevreuxi Gordon \& Monod, 1968

- Male gnathopod 2 propodus palm with posterodistal shelf ..... 3

3. Male gnathopod 2 dactylus short, not reaching end of palm ......... Q. aviceps (K.H. Barnard, 1940)

- Male gnathopod 2 dactylus subequal to palm length

4. Urosome and telson covered in dense setae; male gnathopod 2 propodus anterior margin produced into lobe Q. lobata Asari, 1983

- Urosome and telson without dense setae; male gnathopod 2 anterior margin not produced...... 5

5. Posterior margin of pereopod 7 basis regularly convex, telson with robust setae along inner margins of each lobe Q. sarina Lowry \& Springthorpe, 2005

- Posterior margin of pereopod 7 basis not convex, telson without robust setae along inner margins of each lobe Q. laleyei sp. nov.

6. Telson with robust setae along inner margins of each lobe

- Telson without setae along inner margin of each lobe

Q. bengalensis Stebbing, 1907

7. Epimeron 3 margins smooth.

Q. lutzi (Shoemaker, 1933)

- Epimeron 3 margins with several teeth

8. Accessory flagellum with 7 articles; mandibular palp articles 2-3 without setae

Q. bousfieldi Karaman \& Barnard, 1979

- Accessory flagellum with 9-10 articles; mandibular palp articles 2-3 with setae

.. meufong Hughes \& Haji, 2016

\section{Ecology and distribution}

In the Nokoué lagoon, $Q$. laleyei was sampled periodically at all five sampling sites visited during this study, down to a water depth of at least $1.8 \mathrm{~m}$ (Tables 1-2). Its potential habitat probably extends to the entire lagoon, with a preference for sandy bottoms located near to the entrance of the northern Ouémé and Sô rivers. The levels of abundance observed were highly variable, and associated with the sampling methods (Table 2). The basket method showed the greatest sampling efficiency, principally when collectors were filled with local sediment (see Gnohossou 2006), demonstrating the close relationship of the species to the substratum (endo-/epibenthic behaviour). Its highest abundance (133 ind. $\mathrm{m}^{-2}$ ) was registered with this method at station Embouchure during the flood event of September 2002 (salinity: 0.0 g.L. ${ }^{-1}$; oxygen concentration: $3.8 \mathrm{mg} . \mathrm{L}^{-1}$; depth: $1.8 \mathrm{~m}$; sandy bottom). The few specimens collected with bundles (immersed $30 \mathrm{~cm}$ below the lagoon surface) suggest this benthic species can also swim in the water column searching for food and new favourable habitats. Within the lagoon, this euryhaline amphipod was found to live in a wide range of salinities (between 0 and 22 g.L.- $\mathrm{L}^{-1}$ ), disappearing in southern high salinity areas during the low-water season. Furthermore, it shows some tolerance for pollution, as demonstrated by its presence in areas experiencing low oxygen concentration in the water column (down to $2.5 \mathrm{mg} . \mathrm{L}^{-1}$ at station Ganvié in September 2002). It was also observed to have high abundance in the Ahémé and Porto-Novo lagoons during the flooding period (samples collected with Surber net and the macrophytes method). 
GNOHOSSOU P. \& PISCART C., A new epibenthic species from costal lagoons of Benin

Table 1. Relationship between abiotic environmental variables and densities of the amphipod Quadrivisio laleyei sp. nov. sampled in 2002-2003 at five stations of the Nokoué lagoon (basket sampling method; mean of three replicates at each station).

\begin{tabular}{|c|c|c|c|c|c|c|c|}
\hline & & $\begin{array}{c}\text { Water depth } \\
\text { (m) }\end{array}$ & $\begin{array}{c}\text { Transparency } \\
\text { (m) }\end{array}$ & $\begin{array}{c}\text { Temperature } \\
\left({ }^{\circ} \mathbf{C}\right)\end{array}$ & Salinity & $\begin{array}{l}\text { Oxygen } \\
\left(\mathrm{mg} . \mathrm{L}^{-1}\right)\end{array}$ & $\begin{array}{l}\text { Density } \\
\left(\text { ind.m }{ }^{-2}\right)\end{array}$ \\
\hline June & Zogbo & 1.60 & 0.60 & - & 26.0 & 5.0 & 0.0 \\
\hline \multirow[t]{4}{*}{2002} & Ganvié & 1.10 & 0.35 & - & 10.0 & 8.5 & - \\
\hline & Vêki & 1.20 & 0.35 & - & 16.0 & 7.1 & - \\
\hline & MOR & 1.25 & 0.40 & - & 11.0 & 5.7 & 0.0 \\
\hline & Canal & 1.40 & 0.40 & - & 25.0 & 5.1 & - \\
\hline July & Zogbo & 1.50 & 0.70 & - & 15.0 & 6.7 & 0.0 \\
\hline \multirow[t]{4}{*}{2002} & Ganvié & 1.10 & 0.10 & - & 3.0 & 7.8 & 0.0 \\
\hline & Vêki & 1.40 & 0.60 & - & 10.0 & 7.1 & 21.6 \\
\hline & MOR & 1.40 & 0.10 & - & 0.0 & 6.2 & - \\
\hline & Canal & 1.40 & 0.90 & - & 17.0 & 6.2 & 0.0 \\
\hline August & Zogbo & 1.80 & 0.40 & - & 7.5 & 6.2 & 0.0 \\
\hline \multirow[t]{4}{*}{2002} & Ganvié & 1.15 & 0.10 & - & 0.0 & 3.2 & 0.0 \\
\hline & Vêki & 1.40 & 0.30 & - & 0.0 & 6.7 & 0.0 \\
\hline & MOR & 1.60 & 0.25 & - & 0.0 & 6.5 & 0.0 \\
\hline & Canal & 1.50 & 0.50 & - & 0.0 & 6.4 & 0.0 \\
\hline September & Zogbo & 2.20 & 0.50 & - & 0.0 & 4.6 & 0.0 \\
\hline \multirow[t]{4}{*}{2002} & Ganvié & 1.15 & 0.50 & - & 0.0 & 2.5 & 3.0 \\
\hline & Vêki & 1.50 & 0.55 & - & 0.0 & 3.8 & - \\
\hline & MOR & 1.80 & 0.60 & - & 0.0 & 3.8 & 133.0 \\
\hline & Canal & 1.85 & 0.20 & - & 0.0 & 5.5 & 0.0 \\
\hline December & Zogbo & 1.80 & 1.00 & 33.0 & 7.0 & 10.0 & - \\
\hline \multirow[t]{4}{*}{2002} & Ganvié & 0.80 & 0.50 & 29.4 & 0.0 & 7.5 & - \\
\hline & Vêki & 1.40 & 0.40 & 30.7 & 0.0 & 8.5 & 1.6 \\
\hline & MOR & 1.55 & 0.40 & 31.9 & 0.0 & 6.2 & - \\
\hline & Canal & 1.95 & 0.60 & 31.3 & 0.7 & 10.0 & 0.0 \\
\hline February & Zogbo & 1.75 & 1.00 & 29.8 & 16.0 & 9.0 & 30.0 \\
\hline \multirow[t]{4}{*}{2003} & Ganvié & 1.40 & 0.60 & 29.2 & 16.0 & 7.0 & 0.0 \\
\hline & Vêki & 1.30 & 0.60 & 30.5 & 15.0 & 8.5 & 115.0 \\
\hline & MOR & 1.60 & 0.60 & 29.6 & 15.0 & 6.5 & - \\
\hline & Canal & 1.90 & 0.70 & 28.9 & 16.0 & 10.0 & 0.0 \\
\hline March & Zogbo & 1.40 & 0.90 & - & 33.0 & 9.0 & 0.0 \\
\hline \multirow[t]{4}{*}{2003} & Ganvié & 0.70 & 0.25 & - & 15.0 & 7.0 & 0.0 \\
\hline & Vêki & 0.70 & 0.30 & - & 22.0 & 9.6 & 12.3 \\
\hline & MOR & 1.20 & 0.80 & - & 17.0 & 6.3 & - \\
\hline & Canal & 1.60 & 0.90 & - & 18.0 & 5.7 & 0.0 \\
\hline
\end{tabular}


Table 2. Mean abundances of the amphipod Quadrivisio laleyei sp. nov., sampled with four different methods at five stations of the Nokoué lagoon. Bundle (ind.bundle ${ }^{-1}$ ) and basket (ind. $\mathrm{m}^{-2}$ ) methods: 7 monthly samplings in 2002-2003, $\mathrm{n}=3$; Macrophytes (ind.macrophyte ${ }^{-1}$ ) and Surber (ind. $\mathrm{m}^{-2}$ ) methods: 2 sampling periods (February and September 2006), $(\mathrm{n}=5)$.

\begin{tabular}{lccccc}
\hline & \multicolumn{5}{c}{ Sampling sites } \\
\hline $\begin{array}{l}\text { Sampling methods } \\
\quad \text { MOR }\end{array}$ & Vêki & Ganvié & Zogbo & Canal \\
$\begin{array}{l}\text { Bundle } \\
\text { Macrophyte }\end{array}$ & 0.3 & 8.2 & 0.0 & 0.0 & 7.3 \\
quantitative & 13.0 & 2.0 & 2.2 & 0.4 & 0.4 \\
Basket & & & & & \\
Surber & 44.3 & 37.1 & 0.6 & 5.0 & 0.0 \\
& 7.5 & 1.5 & 0.0 & 0.0 & 0.0 \\
\hline
\end{tabular}

\section{Discussion}

The genus Quadrivisio was created by Stebbing (1907) for the brackish Indian species $Q$. bengalensis. Two species were transferred in this new genus: Pseudoceradocus lutzi Shoemaker, 1933 from Guyana (SE America) and Ceradocus aviceps (Barnard, 1940) from Western Cape (S Africa). Later on, Q. chevreuxi Gordon \& Monod, 1968, found in Zanzibar; Q. bousfieldi Karaman \& Barnard, 1979, found in the outlet of the Liei River, Bismark Archipelago; Q. lobata Asari, 1983, found in India; Q. sarina Lowry \& Springthorpe, 2005, a marine species found in Sarina, Australia and finally Q. meufong Hughes \& Kaji, 2016, a brackish species from Thailand were added. This genus was recently transferred into the new family Maeridae (Lowry \& Hughes, 2009). So far, nine species were attributed to this genus, including the new one herein described. Our study hence confirm the presence of the genus Quadrivisio in West Africa, and the worldwide distribution of this amphipod genus. Indeed, even if, Monod (1951) mentioned a South American species Q. lutzi (Shoemaker, 1933) in the Ebrié lagoon (Bay of Cocody, Ivory coast, W Africa), which was mainly sampled in the roots of Pistia stratiotes L. (salinity range: $0.5-1.3$ g.L $\mathrm{L}^{-1}$ ). There was no detailed description of the specimens collected, and only the anterior parts of male and female specimens were figured.

However, the figured features appear very close to the morphology of $Q$. lutzi, but without any diagnostic value at the species level. Despite having not yet been formally verified on fresh material from the Ebrié lagoon, we suspect that Monod's specimens belong to the new species described herein. Therefore, the known geographical distribution of $Q$. laleyei is currently restricted to the coastal Benin lagoons, but with probable extension into other West African coastal lagoons from Ivory, Ghana, Togo and Nigerian coasts; all of which are located at approximately the same latitude.

\section{Acknowledgements}

This research programme was partly supported by the International Foundation of Science and the CORUS Project $\mathrm{n}^{\circ}$ 99.00.26 ("Etude du fonctionnement écologique des lagunes ouest-africaines") funded by the French Ministry of Cooperation. The authors thank the members of the "Laboratoire d'Hydrobiologie et d'Aquaculture, Faculté des Sciences Agronomiques, Université d'AbomeyCalavi, Bénin" for their support and the local fishermen for their helpful assistance during fieldwork. P. Gnohossou thanks F. Garabetian and Jean Claude Sorbes (Université de Bordeaux 1) for cordial hospitality at Station Marine during Arcachon stays to initiate the description of the new species. 


\section{References}

Adounvo U., Laléyé P., Dauta A. \& Moreau J. 2007. Facteurs écologiques et production halieutique d'une lagune Ouest africaine: le lac Nokoué au Bénin. Journal of Afrotropical Zoology Special issue: $49-55$.

Albaret J.J. 1994. Les poissons: biologie et peuplements. In: Durand J.-R., Dufour P., Guiral D. \& Zabi S.G.F. (eds) Environnement et ressources aquatiques de Côte d'Ivoire. Tome II - Les milieux lagunaires. Éditions de l'ORSTOM, Paris.

Baran E. 1999. Rôle des estuaires vis-à-vis de la ressource halieutique côtière en Guinée. In: Domain F., Chavance P. \& Diallo A. (eds) La pêche côtière en Guinée: ressources et exploitation. Editions IRD/ CNSHB, Paris.

Barnard K.H. 1940. Contributions to the crustacean fauna of South Africa, XII. Further additions to the Tanaidacea, Isopoda and Amphipoda, together with keys for identification of the hitherto recorded marine and freshwater species. Annals of the South African Museum 32: 381-543.

Blaber S.J.M. 2008. Tropical estuarine fishes: ecology, exploitation and conservation. Blackwell Science Ltd., Oxford. https://doi.org/10.1002/9780470694985

Casanova B., Brunet M. \& Segonzac M. 1993. L'impact d'une épibiose bactérienne sur la morphologie fonctionnelle de crevettes associées à l'hydrothermalisme médio-Atlantique. Cahiers de Biologie Marine 34: 573-588.

Gnohossou P. 2006. La faune benthique d'une lagune ouest-africaine (le lac Nokoué au Bénin), diversité, abondance, variations temporelles et spatiales, place dans la chaine trophique. $\mathrm{PhD}$ thesis, Institut National Polytechnique / Ecole Nationale Supérieure Agronomique de Toulouse, France.

Hughes L.E., Kaji T. 2016. Description of a new species of Quadrivisio Stebbing, 1907, from Songkhla Lake, Thailand (Crustacea: Peracarida: Amphipoda: Maeridae). Raffles Bulletin of Zoology 64: 351-359.

Lalèyè P.A. 1995. Ecologie comparée de deux espèces de Chrysichthys, poisson siluriforme (Claroteidae) du complexe lagunaire lac Nokoué - lagune de Porto-Novo. PhD thesis, Université de Liège, Belgium.

Lalèyè P., Niyonkuru C., Moreau J. \& Teugels G.G. 2003. Spatial and seasonal distribution of the ichthyofauna of Lake Nokoué, Benin, West Africa. African Journal of Aquatic Sciences 28: 151-161. https://doi.org/10.2989/16085910309503779

Monod T. 1951. Sur quatre crustacés de la lagune Ebrie (Côte d'Ivoire). Conferencia Internacional dos Africanistas Ocidentais em Bissau Vol. III, Part 2:149-164.

Niyonkuru C. 2007. Etude comparée de l'exploitation et de la démographie des poissons cichlidés dans les lacs Nokoué et Ahémé du Bénin. $\mathrm{PhD}$ thesis, Université d'Abomey-Calavi, Benin.

Pombo L., Elliot M. \& Rebelo J.E. 2002. Changes in the fish fauna of the Ria de Aveiro estuarine lagoon (Portugal) during the twentieth century. Journal of Fish Biology 61 (Supplement A): 167-181.

https://doi.org/10.1111/j.1095-8649.2002.tb01769.x

Shoemaker C.R. 1933. Amphipoda from Florida and the West Indies. American Museum Novitates 598: $1-24$.

Stebbing T.R.R. 1907. The fauna of brackish ponds at Port Canning, Lower Bengal. Part V. Definition of a new genus of Amphipoda, and description of the typical species. Records of the Indian Museum 2: $119-123$.

Villanueva M.C., Lalèyè P., Albaret J.-J., Laë R., Tito de Morais L. \& Moreau J. 2006. Comparative analysis of trophic structure and interactions of two tropical lagoons. Ecological Modelling 197: 461477. https://doi.org/10.1016/j.ecolmodel.2006.03.016 
Villanueva M.C. 2004. Biodiversité et relations trophiques dans quelques milieux estuariens et lagunaires de l'Afrique de l'Ouest: adaptations aux pressions environnementales. $\mathrm{PhD}$ thesis, Institut National Polytechnique de Toulouse, France.

Manuscript received: 21 December 2018

Manuscript accepted: 26 May 2019

Published on:26 June 2019

Topic editor: Rudy Jocqué

Desk editor: Eva-Maria Levermann

Printed versions of all papers are also deposited in the libraries of the institutes that are members of the EJT consortium: Muséum national d'Histoire naturelle, Paris, France; Meise Botanic Garden, Belgium; Royal Museum for Central Africa, Tervuren, Belgium; Royal Belgian Institute of Natural Sciences, Brussels, Belgium; Natural History Museum of Denmark, Copenhagen, Denmark; Naturalis Biodiversity Center, Leiden, the Netherlands; Museo Nacional de Ciencias Naturales-CSIC, Madrid, Spain; Real Jardín Botánico de Madrid CSIC, Spain; Zoological Research Museum Alexander Koenig, Bonn, Germany; National Museum, Prague, Czech Republic. 